\title{
Research on the Enhancement to Xi'an Pension Security System under the Aging Population Environment
}

\author{
Xiaohui Zhu ${ }^{1}$ \\ ${ }^{1}$ Department of Ideological and Political Science, Xi'an International University, \\ Xi'an, China, 710077 \\ 346591653@163.com
}

KEYWORDS: Aging Population; Community Home Care; Care Services in Xi'an

\begin{abstract}
Xi'an is the degree of aging of the deepening of the city, community home care service as a new service pension under Xi'an is an important measure to solve the aging population of pension issues. According to Xi'an community home care problems in order to improve the Xi'an community home care services, the government should increase financial support for community care services to mobilize all social forces to expand the sources of funds of pension services, strengthen infrastructure construction, configuration professional management staff, improve community management capabilities to provide multi-level community-based care services, to build multi-level old-age service system, construction of specialized pension services staff to improve community care services.
\end{abstract}

\section{Introduction}

With the degree of aging of the city continues to develop, pension issues are also increasingly prominent. Xi'an is a typical aging city, the sixth census data shows that in 2010 up to 60 years old in Xi'an 125.68 million, accounting for 14.99 percent of the total population aged 65 or older population reached 714,600 , accounting for the city $8.46 \%$ of the total population. Visible, Xi'an is not only typical of aging and degree of aging in the city continues to deepen. How to give full play to various social forces, to establish a new pension manner consistent with the current situation in Xi'an, pension needs to adapt to the masses is extremely urgent.

\section{Community Support Features}

Xi'an is a long history, rich cultural heritage of the city, people are deeply influenced by traditional culture, home care is the number one choice of pension manner. However, with the deepening of China's family planning, development of market economy, changes in lifestyle, family size is shrinking each year in Xi'an, Xi'an Bureau of the fifth order, according to census data bulletin shows six Xi'an 2000 the average household size is 3.47 people in 2010 reduced to 2.95 people, apparently with the decrease in Xi'an family size, family pension function in weakening. At the same time, competition has become increasingly fierce society as a whole, which makes the traditional family pension has been difficult to satisfy the pension needs of the elderly. The community home-based care as a new way of pension, can enable the elderly living at home, and ancillary services provided by community care a social pension manner. This Endowment way to 
solve the increasingly competitive modern society, due to the hard work of children, development of ambulatory care of the problem can not be the cause of the elderly, so that home care aspiration of the common people has a basis in reality. Moreover, community home care also makes full use of home care facilities, resources relative to the aged care service Koo investment costs are relatively low, more importantly, the elderly living in their own familiar surroundings and social circle, avoiding the elderly in the nursing home pension arising from emotional loneliness, cold feeling. Clearly, community endowment way both fit Xi'an traditional culture and consistent with the actual needs of the masses of residents of old-age, retirement is both an important way to solve the functional weakening of family support, but also a humane way of pension. In recent years, Xi'an Municipal Government attaches great importance to the community home-based care of this new pension model, formulated relevant policies to promote the development of community home-based care services in 2009, unveiled a "Xi'an Municipal Government on Accelerating the development of pension business", "Xi'an City-funded community home care service centers (stations) Regulations "and other documents, these policies to some extent contributed to the development of Xi'an community home-based care services. In 2009, Xi'an has 15 communities start a pilot home care service model. In 2011, the old-age home care service center in Xi'an to 165 at present, community home care has begun a large-scale promotion throughout Xi'an.

\section{The Problems in Xi'an Community Support}

Although the community home-based care as a new way of pension developed rapidly in Xi'an, but for now undertaken Xi'an community care service is still in the exploratory stage, home care services there are still some urgent problems in practice, the main reflected in the following aspects:

Xi'an itself is underdeveloped urban economic development, community care service is new in recent years developed new social care services, community endowment funds currently rely mainly on services provided by the Government, the lack of social organizations and individuals to raise funds through various channels and other channels. Although the government has begun to provide financial support to community-based care services, but limited to its economic strength, a huge gap exists between the funds provided by the Government and the community to meet the most basic needs of home-based care. This severely restricts the expansion of community-based care services, affecting the quality of community care services.

With the development of Xi'an community care services in some communities has been care service infrastructure, and take shape. But on the whole, Xi'an community service facilities are often old, single and service facilities are not standardized. Even in old residential construction because of their age-old lack of infrastructure, and in some new residential function is shown in the majority of their infrastructure is lack of practicality. Lack of infrastructure as well as unreasonable configured community infrastructure directly affect the play function of community endowment, but also reduces the citizens' satisfaction with community home care.

Community Support Xi'an still in the exploratory stage, community management, co-ordination capacity is still relatively low, a lot of community home care service centers lack of professional management staff. Management personnel from the neighborhood committee director of the community or part-time secretary, which makes existing community management staff to take a lot of tasks at higher levels of government and community to send daily management, it is difficult to ensure there is enough time and effort to strengthen the older age groups service management. 


\section{The Way to Increase Community Care Services}

It is based in Xi'an community care problems long way to go to improve community care services from the long-term development of Xi'an community care service point of view, from the following aspects:

Financial support is the prerequisite and basis for the development of Xi'an community care services, the government should pay full attention to financial support for community care services, community care services in the financial allocation should not only respect community care services appropriate tilt, but should with the Xi'an Economic Development and Finance increase revenue year after year to increase community care service system financial investment, consolidate the material foundation for the development of community care services.

Also, the Government should co-ordinate the various social forces, change status of a single Community pension funding sources, and encourage social investment community home care services to support a variety of service companies and individuals involved in community home-based care in accordance with laws of the market to absorb all kinds of social forces, investors will invest in funds community home care business. Encourage social organizations, enterprises and individuals donated to community care services, donations or provide free services for pension charitable donations, the Government may grant its full deduction before payment of corporate income tax and personal income tax. Attract more social funds into community home care services, community home-based care to diversify investments.

Community care service infrastructure is essential to the development of community-based care services on the basis of Community Service for the Aged is perfect is an important criterion to judge the ability of community care government should pay full attention to the construction of infrastructure, the community care infrastructure included social development plan, the cost of community infrastructure included in the government budget to ensure that funds community care service infrastructure. Community infrastructure should be set up scientific and arrangements according to the actual situation of each community, especially for the construction of some of the more distant years old communities supporting the building of infrastructure.

Community care service is both an emerging business is a complicated systematic project, which should solve the funding, many problems of infrastructure and service teams, security, health care, etc., need a comprehensive high-quality, professional ability of the professionals. In the development of community care services undertakings shall be provided with a full-time professional management personnel in accordance with the requirements of Community Development..

Different groups of the elderly their pension different needs, different pension spending power, and the contents of a single pension service is not only increasingly difficult to meet the huge demand for the Aged, and it is difficult to really protect the pension rights of the elderly. Xi'an status quo of community care services should be based on actual demand to expand the Aged care service content, at the same time meet the person's daily life, focusing on elderly mental, spiritual needs. Meanwhile, the Government should actively build to meet the different needs of the elderly community care service system. In this system, first of all, should be established to provide pure basic pension benefit type of community service for less income or no income older age groups within the community, to meet the basic needs of this group of pension. Secondly, the income level of the elderly population in general, the Government provided semi-self nature of community-based care services, namely co-financing paid by the elderly in the community and its government for the cost of this group of pension services, to ensure that this part of the group can really get the services 
they need. And for the higher income levels, pension demand individual requirements can be provided entirely distinct groups of individuals to pay pension services.

Enhance the level of service pension is inseparable from the professional team of construction, the government should carry out effective supervision of the pension for service personnel and teams, establish and improve access to care service personnel, management mechanism. Implementation of pension services in the community care service career practitioners licensing system, vigorously strengthen professional ethics practitioners, professional knowledge and training and other aspects of professional skills. At the same time, rising income levels pension services industry, enhance the social prestige of employees pension services, pension services staff stability, absorption attract college students engaged in community care service business. By government regulation, self-development pension service industry to establish a strong sense of service, high ethical standards, professional knowledge and skills of community-based home care service teams work, and gradually improve community care services teams specialized.

\section{Conclusion}

Community home care services is an important measure to address aging $\mathrm{Xi}$ 'an, as a new thing need to keep in practice research, thinking, adjustment and improvement, the government, society, community make concerted efforts as promoting community health care service sustainable development.

\section{Acknowledgements}

Proj: 2014 Xi’an Social Science Plan Project, No. 14IN22

\section{REFERENCE:}

[1] Xi'an Bureau of Statistics, The Sixth National Population Census Data of Xi'an in 2010, [R]. Http: //Epaper.Xiancn.Com/Xawb/Html/2011-05/25/Content_37285.Htm.

[2] Shi Wenjing. Pension Model Reform of Urban Residents-Taking Xi'an as an Example [J]. Xi'an Social Sciences, 2012, (2).

[3] Xi'an Bureau of Statistics. The Fifth National Census Data Bulletin Http://Www.Zyxpop.Gov.Cn/Show.Asp?ID=729.

[4] Xi'an Bureau of Statistics, the Sixth National Population Census Data of Xi'an in 2010, [R]. Http: //Epaper.Xiancn.Com/Xawb/Html/2011-05/25/Content_37285.Htm.

[5] Luo Yaping, Ru Siyu. Plume of Urban Community Development Services for The Aged Problems and Countermeasures. Taking Xi'an Elderly in The Community Dining Table Example [J]. Xi'an Jiaotong University (Social Science Edition) 2014,34 (5).

[6] Zhang Liangli. Response to Population Aging and Construction Planning [M]. A Social Pension Service System Social Sciences Academic Press, 2006: 256. 